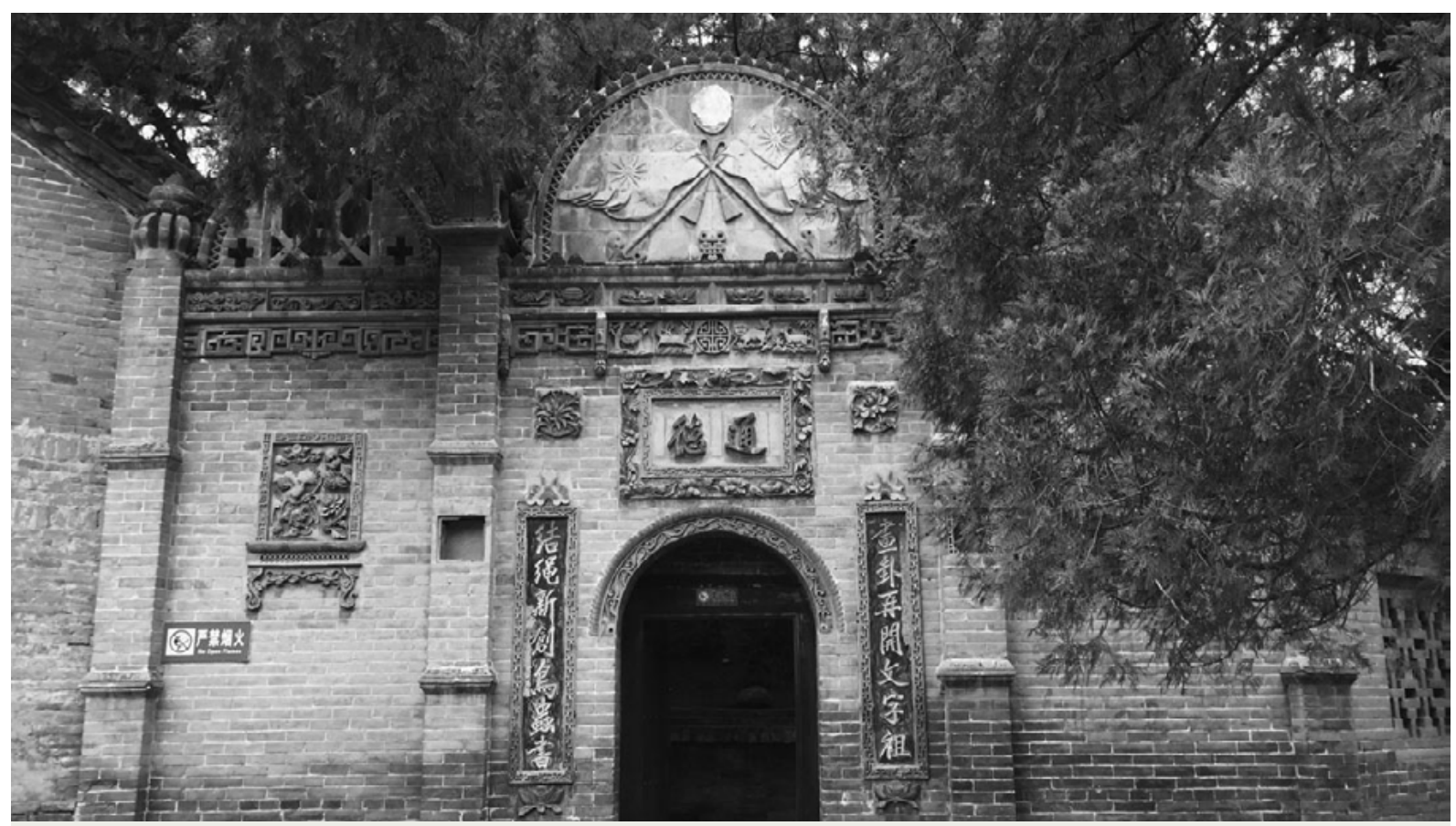

Entrance to the tomb of Cangjie, legendary inventor of writing. As an expression of gratitude and civic virtue, Guomindang general Zhu Qinglan restored this tomb in 1939. The Guomindang and Republican flags are clearly visible above the entrance. Baishui County, Shaanxi, 19 September 2016. PC: Thomas DuBois.

\section{China's Religion Law and the Perils of Counting Consciousness}

\section{Thomas David DuBois}

The academic study of Chinese religion overlaps with, and sometimes confronts, the work of rights advocates. These encounters can be uncomfortable for both parties. Scholars, diplomats, and jurists often have very different ideas of what rights are worth protecting, and what counts as religion. As recent revisions to China's religions law show, ideas about religion in China are changing quickly.
Nearly two decades since China launched its campaign against Falungong, issues of religious freedom remain among the most sensitive and stubborn points of contention between the Chinese government and the international human rights community. Even as the legal protection and regulation of religion has taken on an increasingly global character, China has withstood criticism to stand by certain core principles of how it defines legitimate religious expression.

As a historian of Chinese religion, I occasionally find myself in the unexpected position of explaining and even defending the logic behind China's religion policy. The basic reason is that historians such as myself aim to investigate trends and processes, rather than to engineer them. Our job demands the separation of advocacy from the dispassionate task of understanding what happened and why.

Part of this is the realisation that ideas of human rights and freedoms are themselves 
products of history. Even within the Western world, the genesis and application of religious freedom legislation is by no means static or universal. Looking to China, there is a world of difference between seeking to understand, and seeking to transform, between asking 'what does China value?' and 'why doesn't China value what we want them to?'

\section{Religion in the Eyes of Advocacy}

There is, of course, a great deal of common ground between these two premises, and the best way to find it is by understanding the faults in the ground we stand on. The most effective rights advocacy is that which is able to draw a line between universal ideals and culturally specific practices. Religious freedom is a very good example. Religious freedom is a very laudable ideal, and in some jurisdictions also a legally actionable one. The 1998 passage of the International Religious Freedom Act (IRFA) required the U.S. State Department to annually assess the state of religious freedom in every country, and left open coercive options up to and including sanctions for the worst offenders offenders (U.S. Department of State 1998). Recently, a number of other countries, including Canada, the United Kingdom, Italy, France, and the European Union have followed suit (Hurd 2015), introducing legislation that advocates the promotion of religious freedom at home and abroad.

However, the difference between an ideal and an actionable program is very significant. Putting an assessment of religious freedom into practice forces a general principle through a very specific set of gateways and criteria that will suit some situations better than others. While most states, including China, avow support for the ideal of religious freedom, they differ quite significantly when it comes to defining it. The difference between these views derives less from religion itself than from the place of religion in history. Winnifred Fallers Sullivan (2005), Elizabeth Shakman Hurd $(2008,2015)$ and many others have written extensively and persuasively about the ways that the American legal understanding of religious freedom, including the specific criteria by which IRFA makes its judgments, derive from very specific moments in US history. In contrast, the French view that public space must remain secular has played out most recently in the ban some French cities have levied on Islamic swimwear (aka the 'burkini'), and derives from the deeply egalitarian tendencies of the French Revolution (Decherf 2001).

China, of course, has its own very long, and at times very violent history of organised religion (a term that already presents something of a problem when used historically), and this view will undoubtedly shape how the current Chinese state understands not only the limits, but also the definition of religious freedom, specifically the question of freedom from whom and to what end. While the American view heavily favours the rights of churches to be free from an oppressive state, the Chinese state advocates freedom of the individual conscience from an oppressive clergy, or from foreign interference.

\section{Heresy and the Freedom of Religion}

If we want to see what Hurd calls the 'historical contingency' of how states understand religious freedom, we need look no further than the difference between these two views. Throughout the history of the United States, flight from religious oppression has been a consistent source of new migrants. Not surprisingly, the American legal protection of confessional freedomthat is, the right of organised religions to exist-is very near absolute. In contrast, the history of China has included some very painful experiences with organised religion 
itself. Because the imperial state saw itself as a moral entity that mediated between the sacred realm and the human world, rebellion or other anti-state activity oftentimes started with a competing view of the supernatural, otherwise known as heresy. I use this term very deliberately. As early as the fourteenth century, the legal code of the Ming dynasty demarcated three realms of religion: 'proper' (zheng), 'illicit' (yin) and 'perverse' (xie). The final category was strictly banned precisely because it was real, and thus a source of danger on many levels-as a moral danger to be sure, but also as a gateway for dark magic and demonic forces to infiltrate the realm. For the next five centuries, the imperial state excluded this realm of illegitimate religion from religious choice, in the same way that freedom of speech would not extend to libel or an incitement to violence (DuBois 2012).

Similarly, because official memory often equates Christian mission with imperialism, the Chinese state remains especially vigilant to what it would call foreign domination in the name of religion. Of course, China's experience of Christianity was in reality extremely broad, and included the foundation of many of the country's first modern schools, hospitals, and orphanages. Yet, while the tendency to equate mission with foreign oppression is unquestionably biased, it is by no means new. The country's first modern charity regulations, enacted in late 1920s Shanghai, aimed to curb the influence of foreign benefactors by making it difficult for missions to channel donations to Chinese counterparts (DuBois 2015). Chinese Christians themselves developed a resentment towards the tendency of some foreign missions to view native clergy as churches in perpetual training (Young 2013). Fears in the early years of the People's Republic of China (PRC) that Chinese Christians might already have been brainwashed into acting as a foreign dominated fifth column drove the new government's violent confrontation with the Catholic clergy during the 1950s.
We need not be unduly dismissive of the fact that many of these fears were politically created or exaggerated, because the narrative of history shapes national character regardless of its origin. Part of the Chinese political view of religion in fact comes not from China, but from the experience of the early Soviet Union, which faced in the Russian Orthodox Church a much larger, more politically powerful and more deeply rooted religious enemy than anything that any Chinese state had seen for a thousand years. It was in part from the Soviet experience that China adopted the idea, or at least the rhetoric, that religious freedom was less freedom of a clergy than freedom from it (Gong 2014). The fact that indices of religious freedom used by diplomats and advocates alike often disproportionately emphasise the rights of clergy and clerical organisations should alert us to the potential for conflict down the line.

\section{Religion and Law in China}

At the same time, the 'China first' viewthat everything the Chinese government does or says grows out of China's cultural particularism-has its limits. Not everything can be explained by culture, and certainly not everything should be excused by it. Part of the problem is that there is no culture without power. Whatever its legitimacy, the argument that Asians culturally value stability over democracy (aka the case made for 'Asian values') would likely have gained wider acceptance had it not originated from Malaysia's Mahathir Mohamad and Singapore's Lee Kwan Yew, two of the region's most deeply entrenched political dynasts (Sen 1997). And there is no doubt that just as China has made an art of mobilising the idea of historical victimhood to further its interests, it promotes the idea of cultural difference to deflect human rights criticism, conveniently selecting the elements of culture that are useful at the time (Browne 2016). 
The point here is not to dissuade the promotion of human rights, religious or otherwise, but to understand where the Chinese state is likely to be the most sensitive of criticism, especially in those areas where they would believe themselves to be in the right. A good first step would be to take seriously China's own pronouncements on the issue, especially as they have evolved over the past few years. Beginning with Article 88 of the 1954 Constitution, China's successive legal reforms have all voiced various iterations of support for religious freedom, consistently defined as the freedom of belief (zongjiao xinyang de ziyou) (Constitution of the People's Republic of China 1954). This wording is worth noticing-it was copied directly from previous Chinese constitutions, and before that appeared in Japanese constitutions as early as 1889 . As written, the freedom being promised is closely in concert with Article 18 of the Universal Declaration of Human Rights, which demands 'freedom of thought, conscience and religion' (United Nations General Assembly 1948).

So far so good, as long as religion is defined strictly as individual belief and conscience.

The difficulty begins with the life of religion as a social entity. The same article of the Universal Declaration that speaks of the freedom of thought, also demands that religion find free expression in community with others and in public or private, [manifested] in worship, observance, practice and teaching.' In contrast, the PRC's stance has always been that religion be banned from public life. This assessment featured prominently in the 1982 document titled 'The Basic Viewpoint and Policy on the Religious Question During Our Country's Socialist Period' (zongjiao wenti de jiben guandian he jiben zhengce, more commonly known as 'Document 19'), which is widely seen as the key moment of rehabilitation for religion in the post-Mao era (Central Committee of the CCP 1982). Since the 1994 passage of the 'Rules for the Regulation of Sites for Religious
Activities' (zongjiao huodong changguo guanli tiaoli), China has set aside sites specifically demarcated for religious activity, while at the same time insisting that the rights of religious expression end at the door of the church, mosque or temple. Even with these restrictions in place, only a set number of religions are legally accepted, and each of these is corralled into a Patriotic Religious Organisation (aiguo zongjiao xiehui), overseen by the State Administration of Religious Affairs (guojia zongjiao shiwuju). Very little is left to chance.

China has produced a steady stream of laws, regulations and legal pronouncements on religion (Zhuo 2008). The first full religions law, the 'Regulations on Religious Affairs', was promulgated in 2005, with draft revisions released in September of 2016. Placing the 2005 law and the recent revisions side by side shows continuity in the desire to physically separate organised religious activity from public spaces (DuBois 2016). It also reveals some more recent changes: a growing concern over the spread of information (especially over the Internet), and desire to exert greater control and oversight over the internal finances of religious groups and activities. But even as restrictions on religious activity tighten, the space given to what the law calls 'legitimate' religion is, if anything, growing. Some have even suggested that the Xi Jinping regime may be signalling the emergence of a new and less virulent stage in the campaign against Falungong (Ong and Xie 2016). We should take these trends seriously especially as recent legal reforms suggest that the Chinese state seems genuinely interested in developing and expanding the role of 'social organisations', i.e., civic groups, charities and NGOs.

What is most striking is what the laws neglect. Even if they reveal a certain recalibration of policies towards organised confessional religion, none of the laws as written deal in any way with the real religion of China: the holy trinity of country, party 
and civic virtue. As early as 1974, Joseph Kitagawa first suggested that the worship of Mao Zedong satisfied all of the hallmarks of religion-an organised regimen of worship, a sacred text and a deified founder-an idea that has continued to reverberate with scholars of Chinese religion (Kitagawa 1974). However, I am speaking instead of one variety of what Jose Casanova (1994) has famously called 'public religions', the sort of religion that exists within and undergirds the life of the public sphere. Although the church of politics is no longer mobilised to replace personal loyalties (as in the past, or in Emilio Gentile's 2006 portrayal of secular religion), China's civic religion indeed remains ubiquitous, written into slogans, pictures, commercials and dramas in every conceivable space. If the techniques of dissemination have changed, much of the content-respect for historical paragons, admonitions to pursue knowledge, respect elders and love country-remains true to the moral education first advanced in the early Ming dynasty. Now as then, civic virtues are not optional.

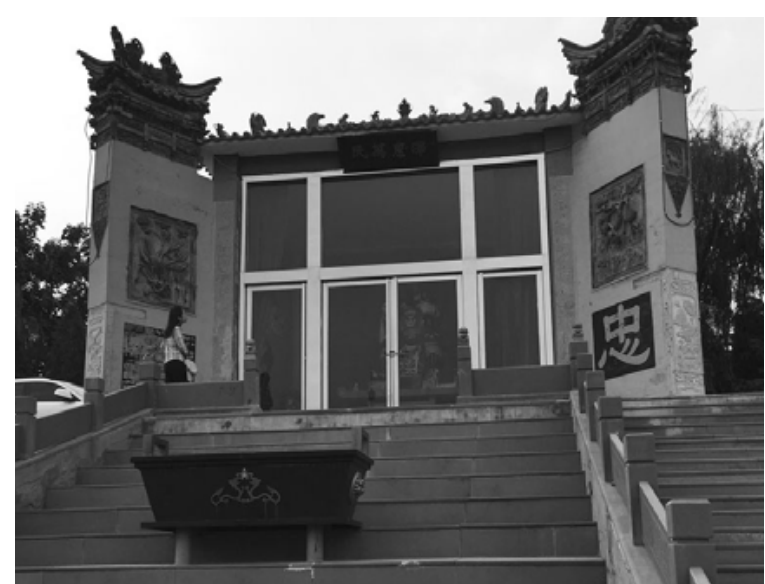

Temple of Guandi, with the character for 'loyalty' in prominent gold paint. This temple shares a courtyard with the Communist Party Headquarters of Beixian Township, Shaanxi, 19 September 2016. PC: Thomas DuBois.

\section{Counting Consciousness}

Returning to the larger problem, I find it striking how often not just the specialised perspective of rights advocacy, but the process of counting and categorising more generally, misrepresents the real state of religion in China. Again, this does not in any way deny the legitimacy of rights advocacy, or of the history of repressing certain religious groups in China-not only Falungong, but also Christianity, Islam, and Tibetan Buddhism. Rather, it simply takes note of how poorly the normative criteria used by diplomatic organs such as IRFA fit the actual practice of religion in the country, both the ubiquitous expressions of public ethics, and very often even the lives of those who consider themselves religious.

Many of the nation's Christians do indeed visit churches, but millions of others, like this elderly woman I recently spoke to in rural Shaanxi, lead a very private Christian life. Asked about the meaning of Christianity, she replied that her religion taught to be kind to others, not to cheat or steal, and to seek spiritual value in suffering (this last point is one that I deal with at some length in most recent book) (DuBois 2017). This woman's religious life, one that she has held dear for decades, is completely internal and individual. It resembles neither the public religion of Chinese nationalism, nor the organised, church-based religion that is the primary concern of the rights community.

Just across the street from this woman's house, other villagers were gathering for the funeral of a woman who had died of cancer. The scene was a hive of activity. Even with teams of specialists hired to do the cooking, perform the rituals, and play the music, there was a job for every member of the community, and importantly for this discussion, absolutely no reason or excuse for opting out. Every member of the community was assigned a task, with names and jobs posted on a large sheet of paper at the doorway of the courtyard. Although the activities would include scriptures and incense, few would have thought of the funeral as a religious function, or of their required presence as 

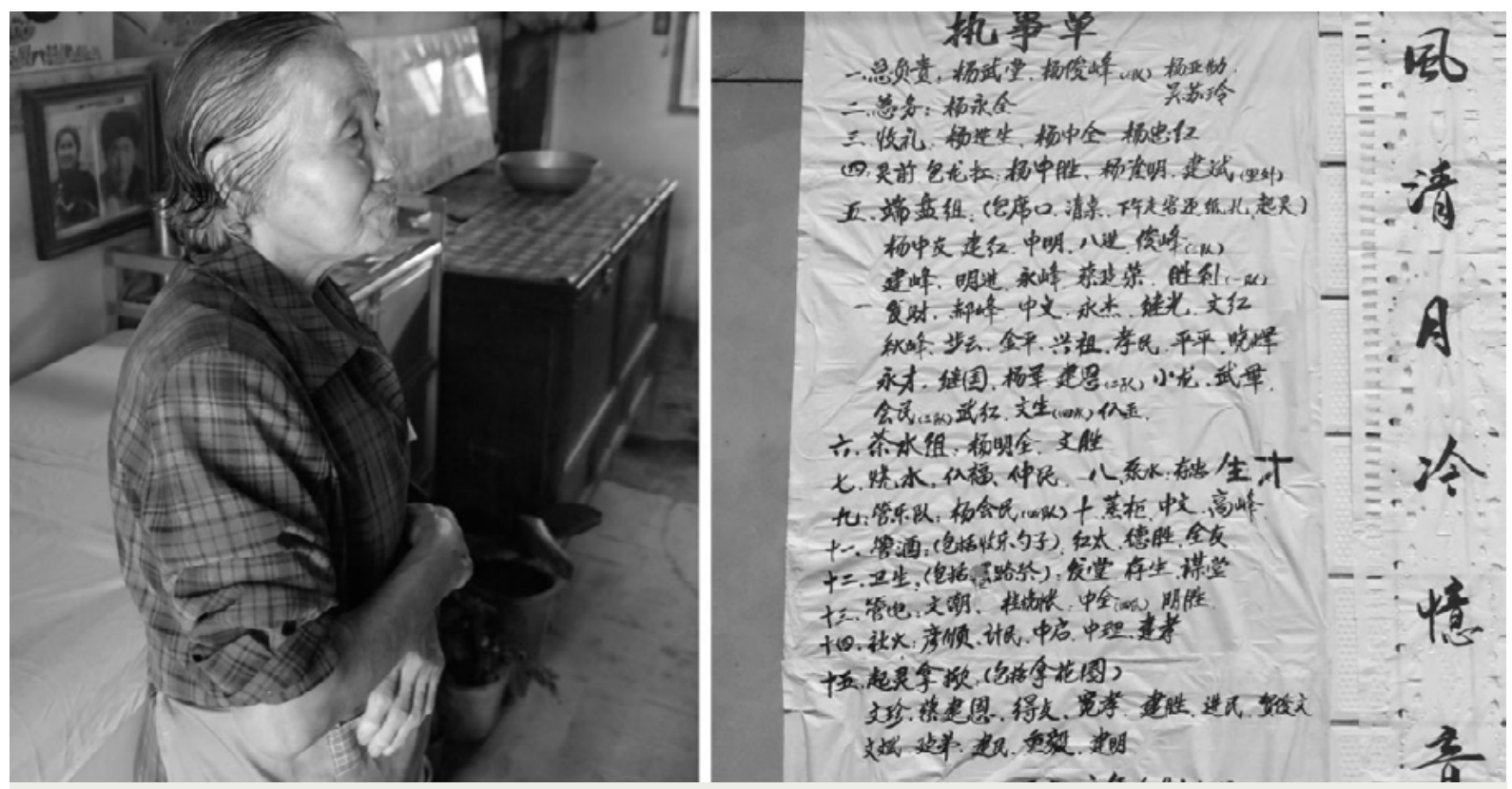

(Left) Christian woman in Gounan Village, Shaanxi, 18 September 2016. Photo by Micah Muscolino. (Right) Roster of duties at village funeral, Gounan Village, Shaanxi, 18 September 2016. PC: Thomas DuBois.

an imposition of religious freedom (the lone Christian had happily taken her place peeling sweet potatoes with the other old women). If anything, they would have described the gathering of the community as goodneighbourliness, or simply common sense.

The difference in vision is not simply one between scholars and advocates. The problem of a field of vision clouded by categories is likely to apply to any overly normative approach to beliefs and ethics. This would include the problem of surveying values, or as the title suggests, counting consciousness. Surveys, such as the often-cited Pew Values Surveys or the big data approach taken by scholars such as Fenggang Yang at the Center on Religion and Chinese Society can produce very useful points of reference, but can also be dangerously misleading (e.g. Gutting 2016) if taken too literally, or read without appreciation of the background issues. Like religion, ideals such as democracy and human rights in reality contain within them a very wide spectrum of ideas and understandings. Simply comparing how respondents in countries as diverse as Korea, Singapore and
Vietnam answer the same questions about these exceedingly complicated concepts cannot tell us much if we do not know what these ideas mean on the ground and in history (Doh 2011). In these cases, survey data alone may obscure more than they reveal, a case of bad information being worse than no information at all. In the end, no amount of surveying can replace a deep and substantive appreciation of history and values in practice.

\section{Thomas David DuBois}

Thomas David DuBois is the author of Sacred Village: Social Change and Religious Life in Rural North China, and Religion and the Making of Modern East Asia. His most recent book, Empire and the Meaning of Religion in Northeast Asia, was published by Cambridge University Press early in 2017. 
This text is taken from Disturbances in Heaven: A Year of Chinese Labour, Civil Society, and Rights, Made in China Yearbook 2016, edited by Ivan Franceschini, Kevin Lin and Nicholas Loubere, published 2017 by ANU Press, The Australian National University, Canberra, Australia. 